\title{
Dusts Control operations in Ririwai Mines, Kano State, Nigeria \\ Amosu C.O.
}

\begin{abstract}
Respirable dust is everywhere (in the surface and underground mine) operations and its environs. Ririwai Tin mine is laden with dust of metallic particles of Arsenic (As), Chromium $(\mathrm{Cr})$, Lead $(\mathrm{Pb})$ and Zinc (Zn). These particles are also found in the soil. Continuous inhalation of dust could lead to irreversible diseases. This paper addresses the control of dust, using previous review of prevailing metallic concentrates. This research answers questions like which are the dust control strategies to be adopted by Ririwai tin mine to obtain best practice? What challenges will Ririwai tin mine face when applying dust control methods in their operation? What is the impact of dust laden with metallic particles on soil, water, vegetation and man in Ririwai tin mine?

Keywords: Ririwai, Dust, Soil, Arsenic, Chromium, Lead, Zinc, Concentration.
\end{abstract}

\section{INTRODUCTION}

Dust generation and its dispersion has been the major concern in open cast mines. Major mining activities in deep open pit mines range from exploration to the processing of end product that primarily contribute particulate matter (PM), dominantly PM10 leading to the problem of air pollution and related health hazards (like pneumoconiosis-black lungs, silicosis and asbestosis). The toxicity of the dust that is generated is dependent on a number of factors, such as the quantity of crystalline silica inhaled, particle size distribution and exposure duration. It has been observed that out of total particulates generated, the PM10 constitute one-third to half. Heavy metals trapped in dusts can cause health problems at higher exposures and destroy aquatic organism when settled and leached into the soil, and into water bodies. Its residues in contaminated habitats may accumulate in microorganisms, aquatic flora and fauna, which in turn enters the human food chain and result in health problems, like the lead poisoning problems in Zamfara State that kills more than 400 children(Galadima and Garba, 2012).

\section{MINE DUST CONTROL}

Dust control has to be built into every aspect of the mines planning and operation. Of critical importance is the workers and people living in the community, who needs to be enlightened of the importance of dust control, the methods which are used, procedures concerned, and the impact on nonadherence to these. The activities which require planned controls include construction, topsoil stripping, blasting, road transport, material handling/transfer systems, and rehabilitation programmes.

Manuscript received on 26 March 2021 | Revised Manuscript received on 07 April 2021 | Manuscript Accepted on 15 October 2021 | Manuscript published on 30 October 2021.

* Correspondence Author

Engr. Amosu C.O.*, Department of Mineral and Petroleum Engineering Yaba College of Technology, Yaba, Nigeria.Email: cyril.amosu@yabatech.edu.ng

(C) The Authors. Published by Lattice Science Publication (LSP). This is an open access article under the CC-BY-NC-ND license (http://creativecommons.org/licenses/by-nc-nd/4.0/)
Work practices then need to be planned so that control measures are integrated. Regulators are increasingly being tasked to manage regional air quality, which means that all sources need to be considered and controls need to be applied where appropriate. In essence this means that mines will increasingly have to manage their impacts through dynamic and regularly maintained source inventories, dispersion modelling and air quality monitoring (Schwegler, 2006).

\section{Hierarchy of Dust Control}

\begin{tabular}{|c|c|c|}
\hline $\mathrm{S} / \mathrm{N}$ & \multicolumn{2}{|c|}{ Dust Mitigation Strategies } \\
\hline \multirow[b]{2}{*}{1} & \multirow[b]{2}{*}{ Elimination } & $\begin{array}{l}\text { T) Treat the dust at its } \\
\text { point of generation }\end{array}$ \\
\hline & & $\begin{array}{l}\text { ii) Treat the dust on its } \\
\text { transmission path using } \\
\text { dust suppression }\end{array}$ \\
\hline \multirow[b]{2}{*}{2} & \multirow[b]{2}{*}{ Substitution } & $\begin{array}{l}\text { i) Use lesser hazardous } \\
\text { substances }\end{array}$ \\
\hline & & $\begin{array}{l}\text { ii) Adopt production } \\
\text { processes that generate less } \\
\text { dust. }\end{array}$ \\
\hline \multirow[t]{2}{*}{3} & \multirow[t]{2}{*}{$\begin{array}{l}\text { Separation/Isolati } \\
\text { on }\end{array}$} & $\begin{array}{l}\text { i) Use of physical } \\
\text { barrier between the dust- } \\
\text { generating task and the } \\
\text { worker. }\end{array}$ \\
\hline & & $\begin{array}{l}\text { ii) Use remotely } \\
\text { operated machinery }\end{array}$ \\
\hline \multirow{6}{*}{4} & \multirow{6}{*}{$\begin{array}{l}\text { Engineering } \\
\text { Control }\end{array}$} & $\begin{array}{l}\text { i) Choose appropriate } \\
\text { equipment }\end{array}$ \\
\hline & & $\begin{array}{l}\text { ii) Replace and maintain } \\
\text { equipment regularly }\end{array}$ \\
\hline & & $\begin{array}{l}\text { iii) Suppress dust by } \\
\text { using water sprays with } \\
\text { additive in water spray. }\end{array}$ \\
\hline & & $\begin{array}{l}\text { iv) Use enclosures (e.g. } \\
\text { covered conveyors, cars, } \\
\text { etc). }\end{array}$ \\
\hline & & $\begin{array}{l}\text { v) Rehabilitate exposed } \\
\text { mine land }\end{array}$ \\
\hline & & $\begin{array}{l}\text { vi) Use ventilation and } \\
\text { filtration to minimise dust }\end{array}$ \\
\hline
\end{tabular}

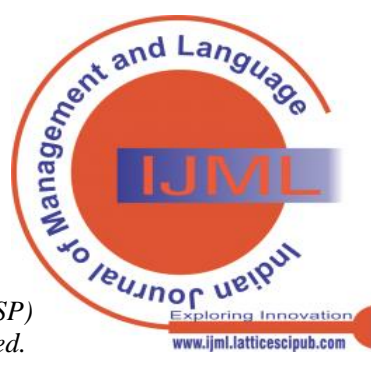




\begin{tabular}{|c|c|c|}
\hline 5 & $\begin{array}{l}\text { Administrative } \\
\text { Control }\end{array}$ & 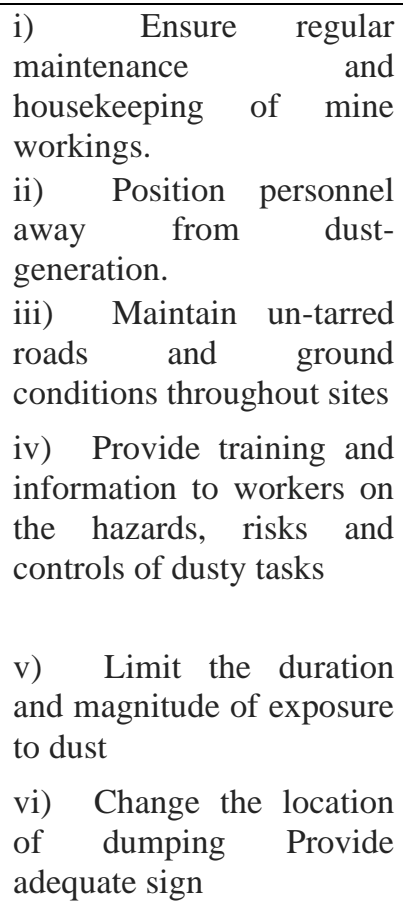 \\
\hline 6 & $\begin{array}{l}\text { Personal } \\
\text { Protective } \\
\text { Equipment }\end{array}$ & $\begin{array}{l}\text { i) Select the most } \\
\text { appropriate respiratory } \\
\text { protection for the task } \\
\text { ii) Ensure training, } \\
\text { comfort and fit testing } \\
\text { iii) Maintain and store } \\
\text { respiratory protective } \\
\text { equipment properly }\end{array}$ \\
\hline
\end{tabular}

\section{LITERATURE REVIEW}

Epidemiological studies in recent years have indicated a strong association between the occurrence of several diseases in humans, particularly cardiovascular disease, kidney related disorders, neurocognitive effects and various forms of cancer and the presence of toxic trace metals (Nwajeiet al, 2012). Mining activities, through milling operations coupled with grinding, concentrating ores and disposal of tailings, along with mill wastewater provide obvious sources of heavy metal contamination of the environment (Ayodele and Mohammed, 2011). Heavy metals can have toxic effects on humans when they contaminate the soil or the ground water pollutant (Kabala and Singh, 2001). Metals contamination in aquatic environmental has received huge concern due to their toxicity, abundance and persistence in the environment and subsequent accumulation in the aquatic habitats (Boamponsemet al, 2010). The Riruwai mining area in Doguwa Local Government Area of Kano State has large deposits of columbite, granite, copper, zinc, lead and uranium (Olure-Bank A. M., 2016). The non-ferrous metallic ores found in Nigeria include lead-zinc ore, tin ore (Cassiterite), niobium ore, uranium ore, and precious metals such as (Gold and Silver) (Furqan, Ibrahim and Sunusi,2020).In 1974, the Geological Survey Department discovered uraniferous pyrochlore in Ririwai hills in Kano
State and Kigo Hills in Plateau State. The grade is $0.012 \%$ uranium oxides(Karniliyus and Ekedegwa, 2006). Uranium occurrence has been reported in Ririwai area of Kano State in peralkaline and peraluminious granites with uranium content of 16-32 ppm (Obajeet al, 2014). Notable cassiterite-bearing veins or lodes and/or greisens occur in the Ririwai, Tibchi, Tongolo and Afu complexes -in decreasing order of mineralisation (Abimbola and Adedibu, 2018).

\section{MATERIAL AND METHODS}

The literature review of metallic particles in dust and soil in the Ririwai tin mine location was captured in this paper. In it, Abdullahi, Garba and Gaiya (2017)presented results using Instrumental Neutron Activation Analytical (INAA) technique which shows $\mathrm{As}, \mathrm{Cr}$ and $\mathrm{Zn}$ having mean concentrations of $4.25 \pm 0.19 \mathrm{mg} / \mathrm{kg}, 43.44 \pm 1.80 \mathrm{mg} / \mathrm{kg}$ and $162.92 \pm 5.43 \mathrm{mg} / \mathrm{kg}$ respectively in dusts across the study area as seen in table 1.Abdullahi, Abigail and Okunola (2018) presented results using Energy Dispersive X-Ray Fluorescence (EDXRF) Spectrometer model FXL83358 which shows $\mathrm{Pb}$, As and $\mathrm{Zn}$ having mean concentrations of $113.54 \pm 3.92 \mathrm{mg} / \mathrm{kg}, 6.76 \pm 0.34 \mathrm{mg} / \mathrm{kg}$ and $216.89 \pm 5.74 \mathrm{mg} / \mathrm{kg}$ respectively in the soil across the study area seen in table 1. Zakari, Nasiru, Ahmed and Abdullahi (2015)presented results using Liquid Scintillation Analysis (LSA) which shows tailing bearing water, surface water source and domestic wate having mean value of 3.04 $\pm 0.14 \mathrm{~Bq} / \mathrm{L}, 2.51 \pm 0.13 \mathrm{~Bq} / \mathrm{L}$ and $2.23 \pm 0.11 \mathrm{~Bq} / \mathrm{L}$ seen in table 1 .

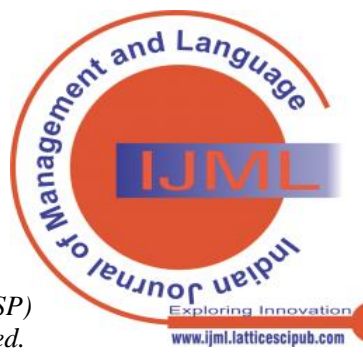




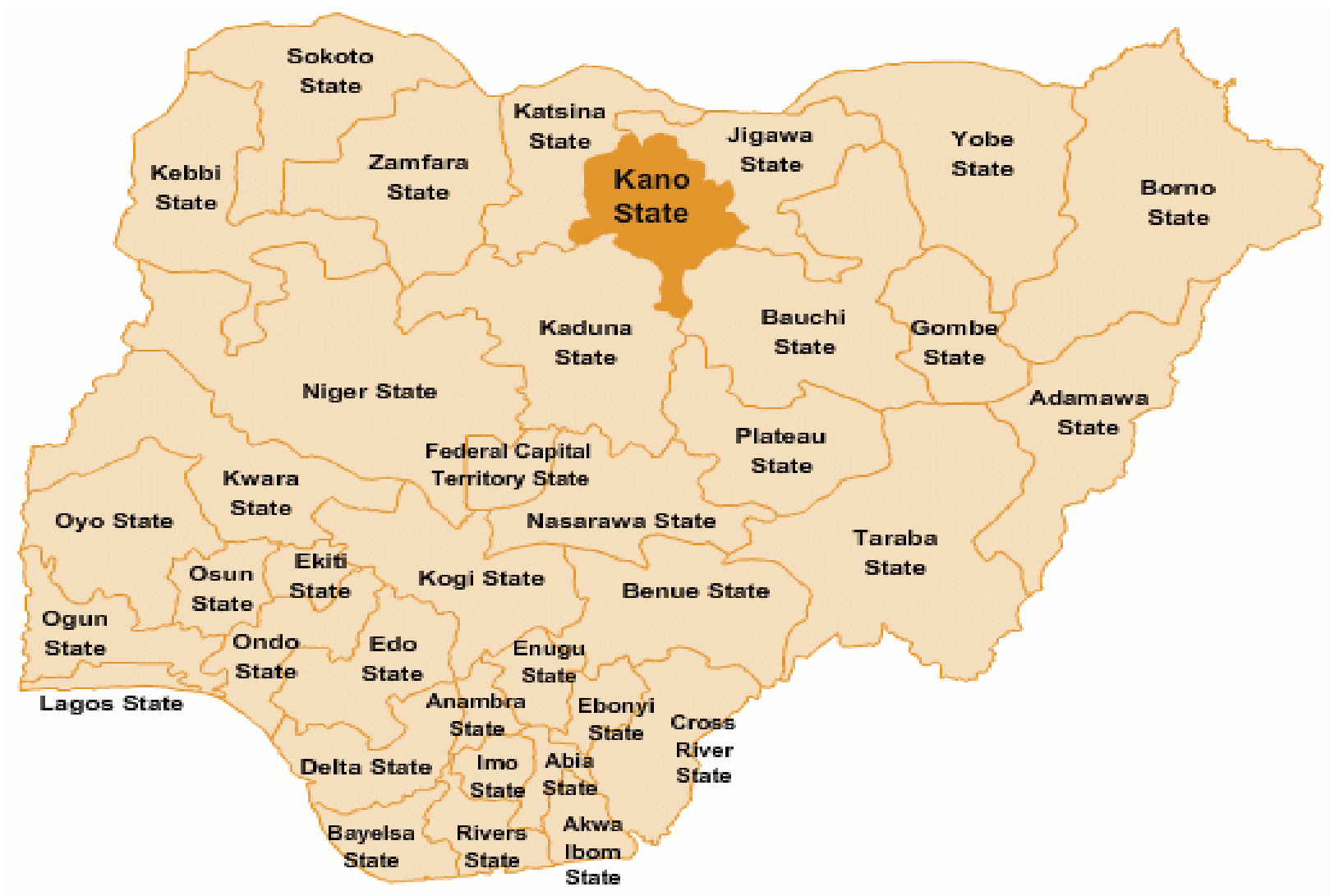

Figure 1: Map of Nigeria showing study area, Kano State.)

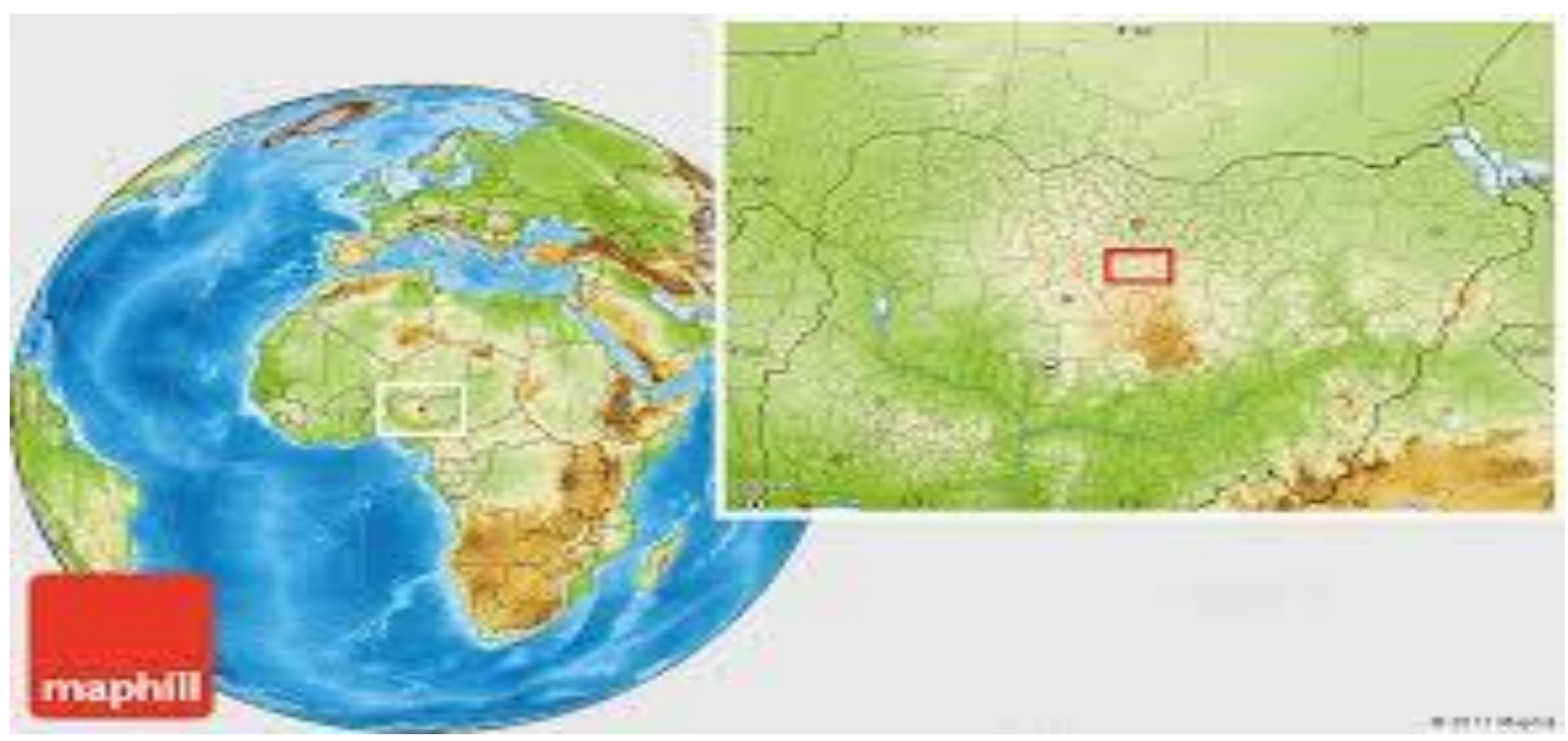

Figure. 2: Geographical Map of Ririwai (maphil.com)

\section{GEOLOGY OF RIRIWAI TIN MINE}

It is located between latitudes $8.41-8.480 \mathrm{E}$ and longitudes $10.4-10.480 \mathrm{~N}$. It measures about $17 \mathrm{~km} \times 16 \mathrm{~km}$ and covers a land area of about $180 \mathrm{~km}^{2}$. It is situated approximately $140 \mathrm{~km}$ south of Kano in Doguwa Local Government Area (Muhammad, 2017). Riruwai is at the end of Kano south where it is bordered curve-linearly by Kaduna state at south and west. It shares a border with Bauchi by East and Tudun Wada at North. It has a distance of over $150 \mathrm{~km}$ from Kano city and hence has more interaction with Kaduna and Plateau states due to their proximity (Ibrahim, 2019). The Ririwai(or Liruei) of northern Nigeria is nonorogenic with a ring-complex and an outer ring dyke of granite porphyries surrounding down-faulted volcanic and basement rocks with a core of composite granitic rocks made up of biotite, aegirine arfvedsonite and albite arfvedsonite granites (Ogunleye and Garba, 2006). It is greisenized granite with related quartz veins. The Mesozoic Younger Granite ring complexes form part of a wider province of alkaline anorogenic magmatism. The granitic rocks are characterized by high values of $\mathrm{Sn}, \mathrm{Nb}, \mathrm{Zn}, \mathrm{Ta}, \mathrm{Li}$, $\mathrm{Rb}$, and $\mathrm{F}$ but ore-forming processes are related to postmagmatic changes.

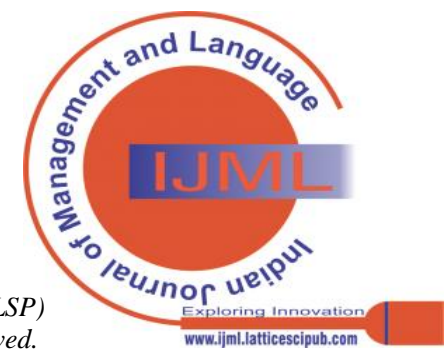


They occur in a zone $200 \mathrm{~km}$ wide and 1,600 km long extending from northern Niger to south central Nigeria (Nuhu, 2009). Ririwai is owned and managed bt the Nigeria Mining Corporation. Its declared mineral reserves stands as: Measured (582,668t- $0.7 \%$ Sn, 2.56\% Zn); Indicated $(2,247,683 t-0.61 \% \mathrm{Sn}, 2.05 \% \mathrm{Zn})$ and Demonstrated (2,830,351t - 0.63\% Sn, 2.15\% Zn - (Musa, 2014).

The scope of this study aims and targetsRiriwai underground tin mine that was closed in 1984. It sought to establish and propose best dust control methods using literature review of metallic particles in dust and soil in the location. It will be beneficial in suggesting helpful methods of dust control and hence provide clues to preserve the environment through the methods. This research is significant to address dust control methods in Ririwai tin mine which will add its quota to sustainable policy-making at the industry level. The Limitation of this work is proximity, time and insufficient information from the internet. Researchers chose to study dust control in Ririwai Tin mine as it impacts on the environment.

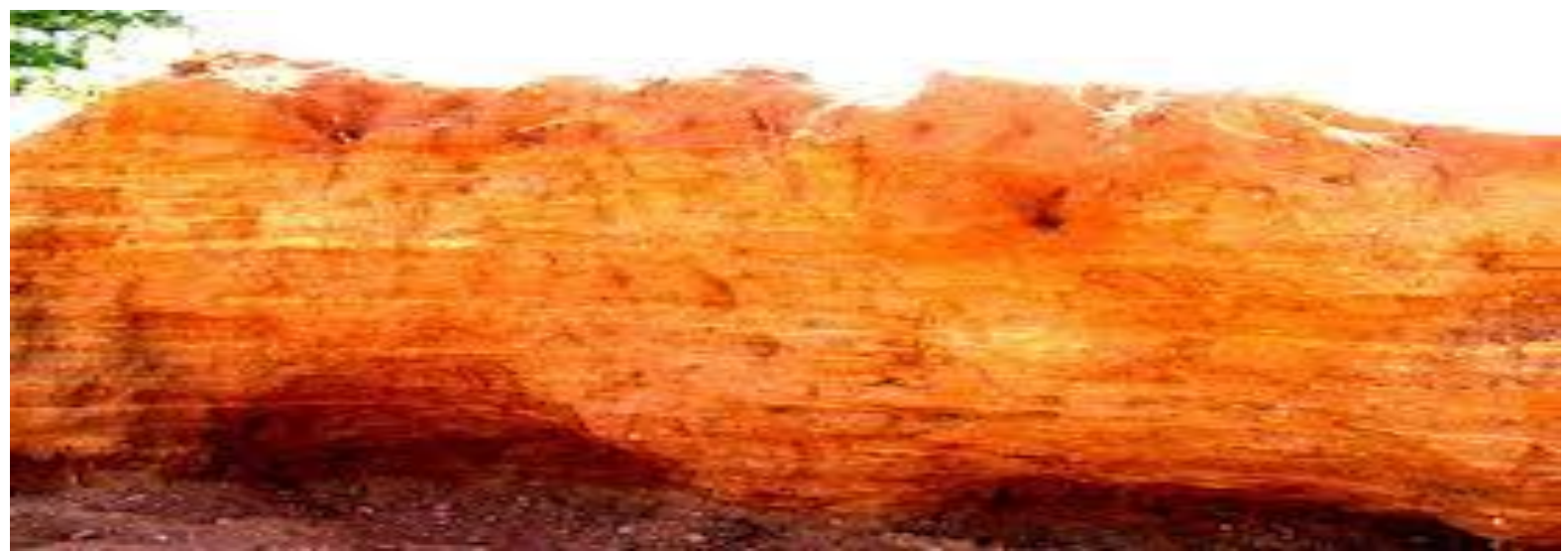

Figure 3A:Opencast mining site in Riruwai; Source: Adopted from Umar 2016

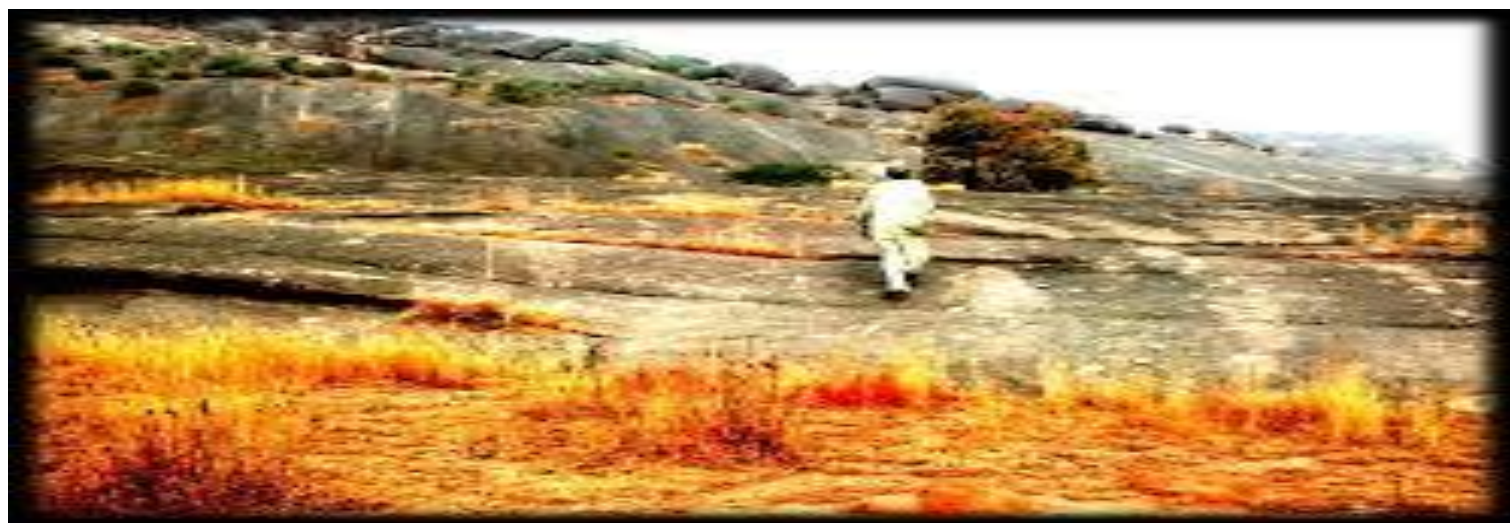

Figure. 3B : Destroyed terrain after open cast mining in the area; Source: Adopted from Umar 2016

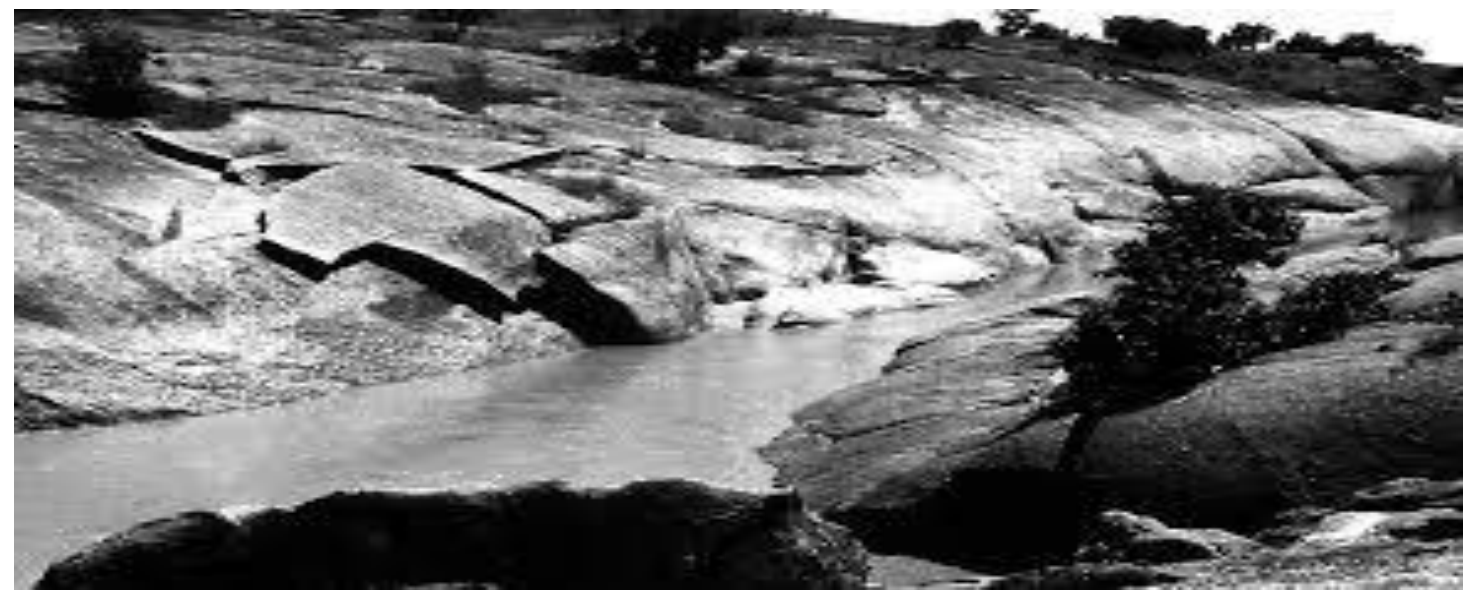

Figure 4: Ririwai tin mine Outcrop

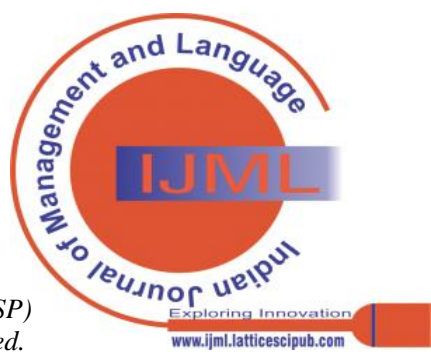



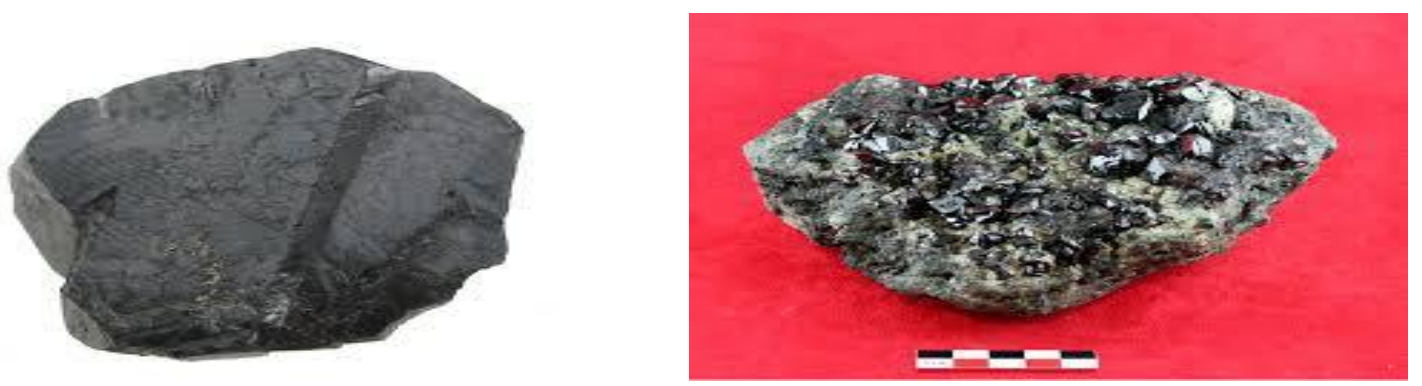

Figure 5: Ririwai tin ore

\section{DATA AND METHODOLOGY}

Data Review and Analysis

Table 1: Mean values for different analysis techniques used on Ririwa tin mine location

\begin{tabular}{|c|c|c|c|c|c|}
\hline \multirow[b]{2}{*}{ Metallic Particles } & \multirow[b]{2}{*}{$\begin{array}{l}\text { In dust using } \\
\text { INNA (mg/kg) }\end{array}$} & \multirow[b]{2}{*}{$\begin{array}{c}\text { In soil using } \\
\text { EDXRF } \\
\text { (mg/kg) }\end{array}$} & \multicolumn{3}{|c|}{ In water using LSA (mg/L) } \\
\hline & & & $\begin{array}{c}\text { In tailing } \\
\text { bearing water } \\
(\mathrm{Bq} / \mathrm{L})\end{array}$ & $\begin{array}{c}\text { In surface } \\
\text { water } \\
(\mathrm{Bq} / \mathrm{L})\end{array}$ & $\begin{array}{c}\text { In domestic } \\
\text { water } \\
(\mathrm{Bq} / \mathrm{L})\end{array}$ \\
\hline Lead, Pb & & $113.54 \pm 3.92$ & & & \\
\hline Arsenic, As & $4.25 \pm 0.19$ & $6.76 \pm 0.34$ & & & \\
\hline Zinc, Zn & $162.92 \pm 5.43$ & $216.89 \pm 5.74$ & & & \\
\hline Chromium, $\mathrm{Cr}$ & $43.44 \pm 1.80$ & & & & \\
\hline Tin, Sn & & & & & \\
\hline Radon, Rn & & & $3.04 \pm 0.14$ & $2.51 \pm 0.13$ & $2.23 \pm 0.11$ \\
\hline
\end{tabular}

Comparing Data of Metallic Particles Concentration in the Dust and In the Soil Using Inna (Abdullahi, Garba and Gaiya, 2017) and Edxrf (Abdullahi, Abigail And Okunola, 2018).

Abdulllahi, Garba, and Gaiya (2017)collected ten (10) dust samples on filter papers mainly within the Ririwai tin mines inside active pits using air sampler in some locations and stating the concentration of As, $\mathrm{Cr}$ and $\mathrm{Zn}$ in table 2.

Table 2: Sampling locations and the concentration of As, $\mathrm{Cr}$ and $\mathrm{Zn}$ in dust samples

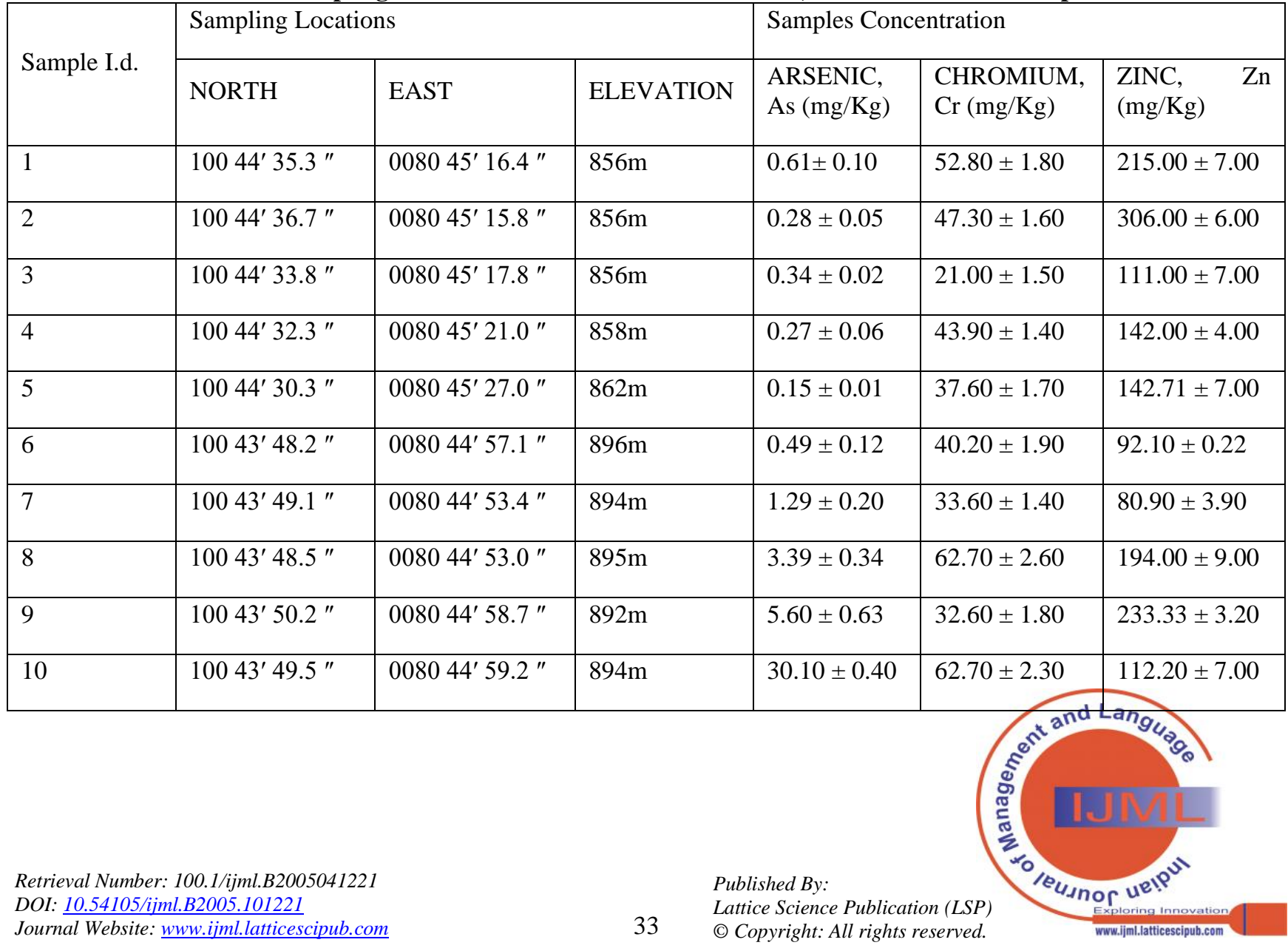


Dusts Control operations in Ririwai Mines, Kano State, Nigeria.

\begin{tabular}{|l|l|l|l|l|l|l|}
\hline Mean & & & & $4.25 \pm 10.19$ & $43.44 \pm 1.80$ & $162.92 \pm 5.43$ \\
\hline Maximum & & & & $30.10 \pm 0.63$ & $62.70 \pm 2.60$ & $306.00 \pm 9.00$ \\
\hline Minimum & & & & $0.15 \pm 0.01$ & $21.00 \pm 1.40$ & $80.90 \pm 0.22$ \\
\hline $\begin{array}{l}\text { Standard } \\
\text { Deviation }\end{array}$ & & & & $8.778569 \quad \pm$ & $12.67716 \quad \pm$ & $68.53087 \quad \pm$ \\
\hline
\end{tabular}

Also, Abdullahi, Abigail, Okunola (2018) collected ten (10) soil samples at ten different locations around the study

area, at $10 \mathrm{~cm}$ depth of digging, stating the concentrations for $\mathrm{Pb}$, As and $\mathrm{Zn}$ in table 3.

Table 3: Concentration of $\mathrm{Pb}$, As and $\mathrm{Zn}$ in soil samples

\begin{tabular}{|l|l|l|l|l|}
\hline \multicolumn{5}{|l|}{ Concentration In (Mg/Kg) } \\
\hline Serial Number & Identification & Zinc (Zn) & Arsenic (As) & Lead (Pb) \\
\hline 1 & Sample 1 & $420.55 \pm 7.68$ & $5.85 \pm 0.35$ & $189.40 \pm 4.76$ \\
\hline 2 & Sample 2 & $161.78 \pm 5.16$ & $5.20 \pm 0.28$ & $100.24 \pm 3.68$ \\
\hline 3 & Sample 3 & $57.58 \pm 3.62$ & $5.62 \pm 0.40$ & $347.75 \pm 2.78$ \\
\hline 4 & Sample 4 & $75.04 \pm 3.93$ & $6.34 \pm 0.24$ & $65.22 \pm 3.06$ \\
\hline 5 & Sample 5 & $60.19 \pm 3.56$ & $5.94 \pm 0.22$ & $62.64 \pm 2.93$ \\
\hline 6 & Sample 6 & $181.64 \pm 5.39$ & $7.22 \pm 0.55$ & $69.71 \pm 3.31$ \\
\hline 7 & Sample 7 & $188.18 \pm 5.90$ & $8.55 \pm 0.31$ & $114.07 \pm 4.12$ \\
\hline 8 & Sample 8 & $178.29 \pm 5.77$ & $8.10 \pm 0.31$ & $118.10 \pm 4.14$ \\
\hline 9 & Sample 9 & $581.34 \pm 9.64$ & $9.16 \pm 0.42$ & $218.00 \pm 5.64$ \\
\hline 10 & Sample 10 & $264.31 \pm 6.72$ & $5.60 \pm 0.35$ & $150.30 \pm 4.73$ \\
\hline Mean & & $\mathbf{2 1 6 . 8 9} \pm \mathbf{5 . 7 4}$ & $\mathbf{6 . 7 6} \pm \mathbf{0 . 3 4}$ & $\mathbf{1 1 3 . 5 4} \pm 3.39$ \\
\hline
\end{tabular}

\section{RESULTS AND DISCUSSION}

Re-Calculating and Re-Organizing Table 2 and 3 / Plotting Their Graphs

Table 4: Metallic concentrates in Dust

\begin{tabular}{|l|l|l|}
\hline \multicolumn{3}{|l|}{ Concentration In (Mg/Kg) } \\
\hline Arsenic, As & Chromium, Cr & Zinc, Zn \\
\hline 0.14 & 19.50 & 77.00 \\
\hline 0.16 & 22.50 & 84.80 \\
\hline 0.21 & 30.80 & 91.88 \\
\hline 0.23 & 32.20 & 92.32 \\
\hline 0.32 & 32.20 & 104.00 \\
\hline 0.33 & 34.40 & 105.20 \\
\hline 0.33 & 35.90 & 118.00 \\
\hline 0.36 & 38.30 & 119.20 \\
\hline 0.37 & 39.30 & 135.71 \\
\hline 0.51 & 42.10 & 138.00 \\
\hline 0.61 & 42.50 & 146.00 \\
\hline 0.71 & 45.30 & 149.71 \\
\hline 1.09 & 45.70 & 185.00 \\
\hline
\end{tabular}

Table 5: Metallic concentrates in the soil

\begin{tabular}{|l|l|l|}
\hline \multicolumn{3}{|l|}{ Concentration In $(\mathrm{Mg} / \mathrm{Kg})$} \\
\hline Arsenic $(\mathrm{As})$ & Lead $(\mathrm{Pb})$ & Zinc $(\mathrm{Zn})$ \\
\hline 4.92 & 44.97 & 53.96 \\
\hline 5.25 & 50.53 & 56.63 \\
\hline 5.48 & 59.71 & 61.20 \\
\hline 5.50 & 62.16 & 63.75 \\
\hline 5.22 & 65.57 & 71.11 \\
\hline 5.72 & 66.40 & 78.97 \\
\hline 5.95 & 68.28 & 156.62 \\
\hline 6.02 & 73.02 & 166.94 \\
\hline 6.10 & 96.56 & 172.52 \\
\hline 6.16 & 103.92 & 176.25 \\
\hline 6.17 & 109.95 & 182.28 \\
\hline 6.58 & 113.96 & 184.06 \\
\hline 6.67 & 118.19 & 187.03 \\
\hline & & and Lan \\
\hline
\end{tabular}




\begin{tabular}{|l|l|l|}
\hline 1.49 & 48.90 & 203.00 \\
3.05 & 51.00 & 208.00 \\
\hline 3.73 & 54.60 & 222.00 \\
\hline 4.97 & 60.10 & 230.13 \\
\hline 6.23 & 60.40 & 236.53 \\
\hline 29.70 & 65.00 & 300.00 \\
\hline 30.50 & 65.30 & 312.00 \\
\hline
\end{tabular}

\begin{tabular}{|l|l|l|}
\hline 7.77 & 122.24 & 194.08 \\
7.79 & 145.57 & 257.59 \\
\hline 8.24 & 155.03 & 271.03 \\
\hline 8.41 & 184.64 & 412.87 \\
\hline 8.74 & 194.16 & 428.23 \\
\hline 8.86 & 212.36 & 571.70 \\
\hline 9.58 & 223.64 & 590.98 \\
\hline
\end{tabular}

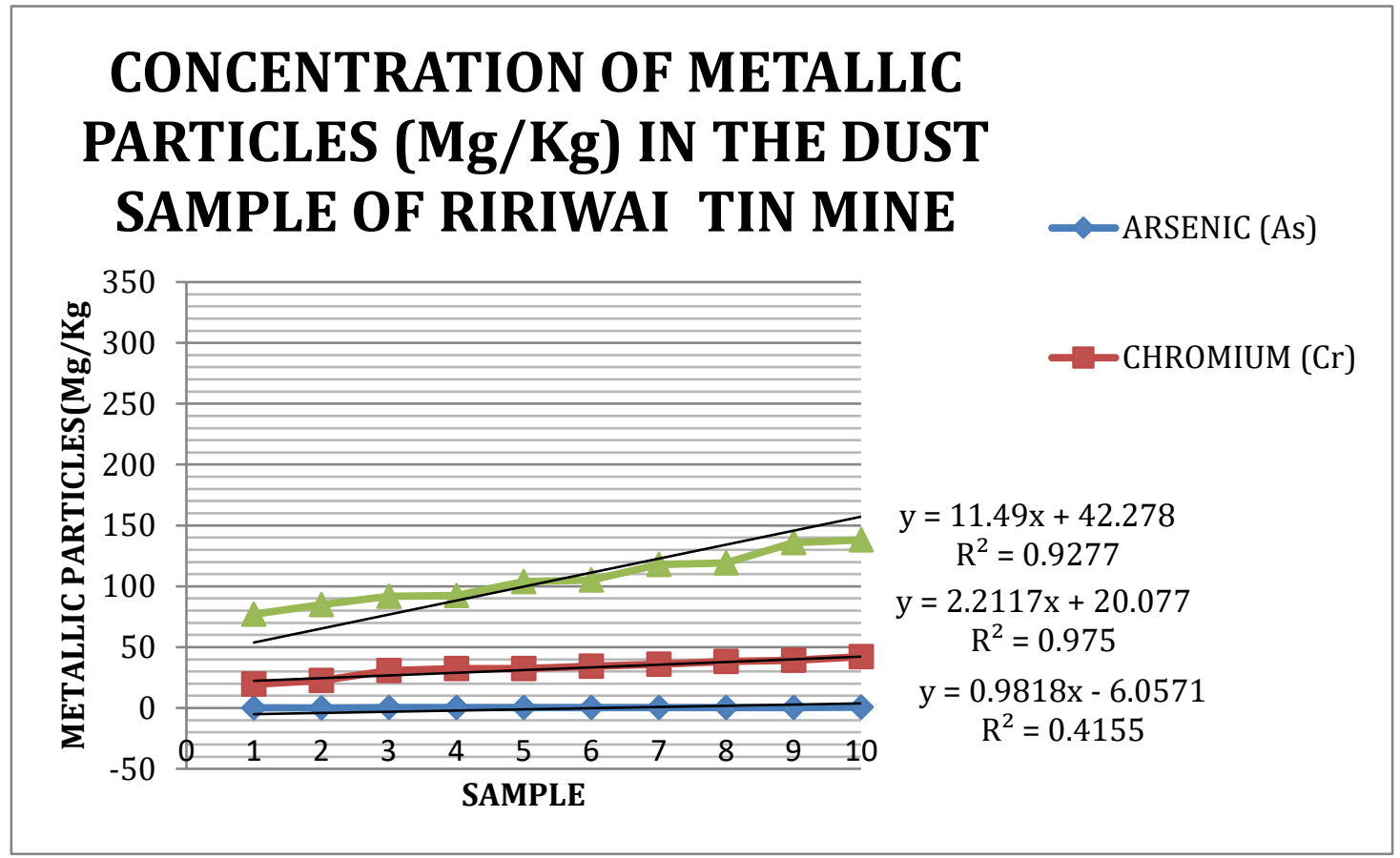

Figure 6: Metallic concentrates in the dust particles of Ririwai tin mine

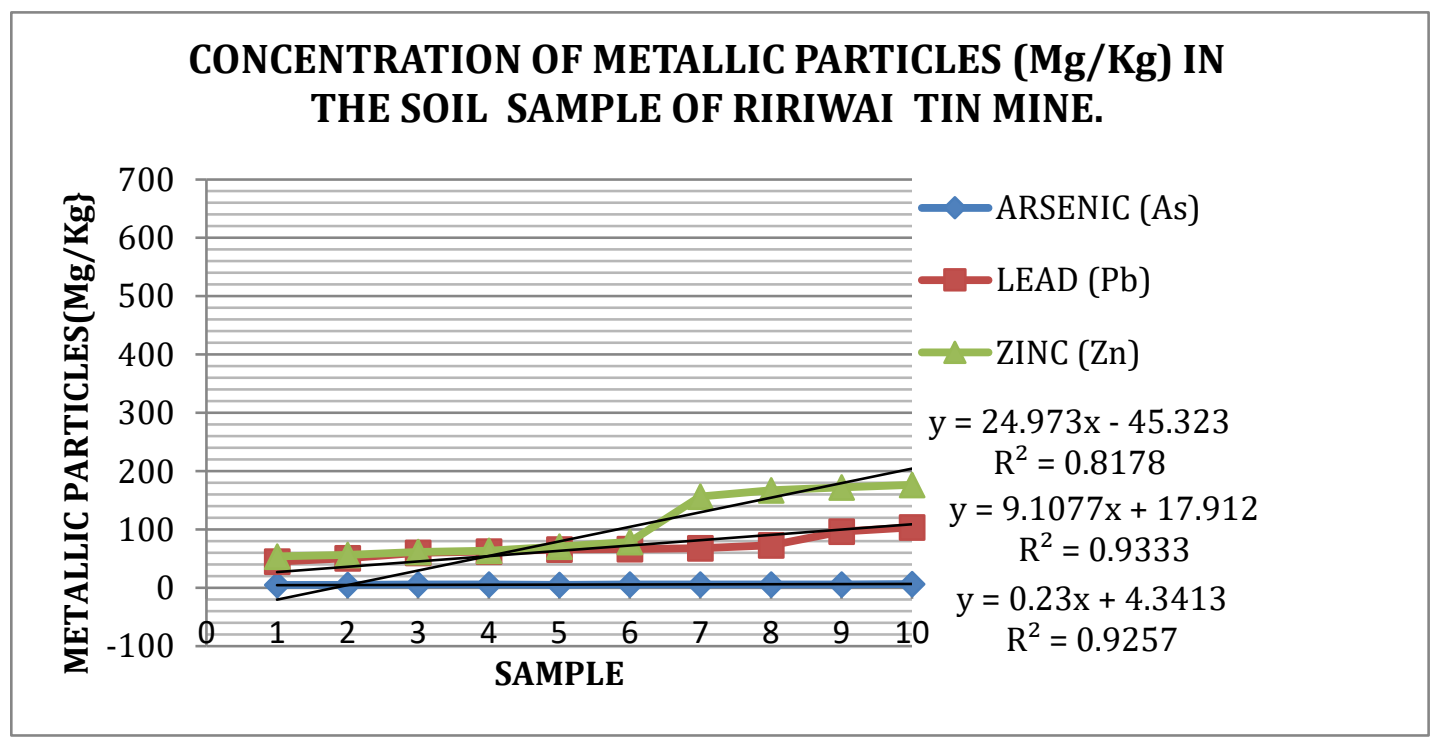

Figure 7: Metallic concentrates in the soil particles of Ririwai tin mine

Table 6: Equations for Linear Plots and Regressions

\begin{tabular}{|l|l|l|l|l|}
\hline Environment & Metallic Particles & Linear Equation & Regression & Gradient (Dy/Dx) \\
\hline \multirow{5}{*}{ IN DUST } & Arsenic(As) & $\mathrm{y}=0.981 \mathrm{x}+6.057$ & $\mathrm{R}^{2}=0.415$ & 0.981 \\
\cline { 2 - 5 } & Chromium(Cr) & $\mathrm{y}=2.211 \mathrm{x}+20.07$ & $\mathrm{R}^{2}=0.975$ & 2.211 \\
\cline { 2 - 5 } & Zinc (Zn) & $\mathrm{y}=11.49 \mathrm{x}+42.27$ & $\mathrm{R}^{2}=0.927$ & 11.49 \\
\hline
\end{tabular}




\begin{tabular}{|l|l|l|l|c|}
\hline & Arsenic(As) & $\mathrm{y}=0.23 \mathrm{x}+4.341$ & $\mathrm{R}^{2}=0.925$ & 0.23 \\
\cline { 2 - 5 } IN SOIL & Lead (Pb) & $\mathrm{y}=9.107 \mathrm{x}+17.91$ & $\mathrm{R}^{2}=0.933$ & 9.107 \\
\cline { 2 - 5 } & Zinc $(\mathrm{Zn})$ & $\mathrm{y}=24.97 \mathrm{x}-45.32$ & $\mathrm{R}^{2}=0.817$ & 24.97 \\
\hline
\end{tabular}

From table 6, it can be deduced that the distribution of Arsenic, Chronium and Zinc in dust has a distribution value of $0.98 \mathrm{mg} / \mathrm{Kg}, 2.211 \mathrm{mg} / \mathrm{kg}$ and $11.49 \mathrm{mg} / \mathrm{kg}$ respectively. So also, the spread of Arsenic, Lead and Zinc in the soil are $0.23 \mathrm{mg} / \mathrm{Kg}, 9.107 \mathrm{mg} / \mathrm{kg}$ and $24.97 \mathrm{mg} / \mathrm{kg}$ respectively. I therefore confirm the concentration of zinc to be the highest which agrees with the results cited in literature of study. According to the regression correlation coefficient, there is variation in the samples from the dust and the soil. The regression variation in concentration of Arsenic is higher in the dust than in the soil. Thus, the need for this paper to consider 'dust control' since Arsenic is highly hazardous to the environment.

\section{CONCLUSION} still prevalence of metallic particles in the dust around its locality and in the soil. This may seriously affect the health of people living in the mining environment. Dust controls should thus be built into all mine areas that surrounds it. These controls will put checks to reduction and considerable elimination.

\section{REFERENCES}

1. Abdullahi M. A., Abigail E. A., Okunola M. R. (2018): Analysis of $\mathrm{Pb}, \mathrm{AS}$ and $\mathrm{Zn}$ Concentration in soil around Ririwai Tin Mine, Kano State, North Western Nigeria, International Journal of Science and Engineering Applications, Volume 7, Issue 09, 291-293. [CrossRef]

2. Abdulllahi M.A., Garba N.N., and Gaiya S. (2017): Assessment of As, $\mathrm{Cr}$ And ZnConcentrations in Dust around Ririwai Tin Mine, Kano State North Western Nigeria, American Journal of Engineering Research (AJER), Volume 6, Issue 12, pp-243-246.

3. Abdullahi M. A., Abigail E. A. and Okunola M. R. (2018): Analysis of $\mathrm{Pb}$, As and $\mathrm{Zn}$ Concentration in soil around Ririwai Tin Mine, Kano State, North Western Nigeria; International Journal of Science and Engineering Applications, Volume 7, Issue 09,291-293. [CrossRef]

4. Abdulllahi M.A., Garba N.N. and Gaiya S. (2017): American Journal of Engineering Research (AJER), Volume 6, Issue 12, pp-243-246.

5. Abimbola C. O. and Adedibu S. A. (2018): Tin Mineralisation in Nigeria - A Review; Environmental and Earth Sciences Research Journal, Vol. 5, pp. 15-23. [CrossRef]

6. Anand K., (2015): Dust Transportation and Settling within the Mine Ventilation Dust Transportation and Settling within the Mine Ventilation Network, Global NEST Journal, Vol. 17, pp 825-834. [CrossRef]

7. Ayodele J.T and Mohammed S.S. (2011): .Zinc Speciation in maize and soils, ResJ. Chem. Sci. 1(4), 98 - 108.

8. Boamponsem L. K., Adam J. I., Dampane S.B. Owusu-Ansah E. and Addae G. (2010): Heavy Matals, Lavel in Stream of Tarkwa gold mining areas of Ghana, J. Chem. Pham res, 2 (3): 504-52.

9. Furqan A., Ibrahim A. R., Sunusi M. M. (2020): Trends in Characterization and Beneficiation of Non-ferrous Metallic Ores in Nigeria, pp 47-55. [CrossRef]

10. Galadima A. and Garba Z. N. (2012): Heavy metals pollution in Nigeria; Causal and consequences; Elixer pollution (45).

11. Ibrahim B. L. (2019): 'Forgetting to Remember': The Fate of Riruwai Old TinMining Communities in Kano State, department of Earth and Environmental Sciences, Vol. 1, No. 2., 265-280

12. Kabala C and Singh B.R. (2001): Fractional mobility of copper, lead and zinc in soil profiles in the vicinity of a copper smelters; J. Environ. Qual. 30485 - 492[CrossRef]

13. Karniliyus J.S. And Ekedegwa A.I.G. (2006): Uranium Potential in Nigeria, Page 193 - 195.Musa M. S. (2014): Investment Opportunities In Nigeria's Minerals And Metals Sector; Ministry of
Though Ririwai tin mine closed up in 1984, yet there is Geography, Bayero University, Kano, Nigeria; African Journal of

Mines and Steel Development, Federal Republic of Nigeria; AfricaLondon Summit.

14. Muhammad A.A.(2017): Assessment Of Radiological Hazards Around Ririwai Tin Mines, Kano State, North Western Nigeria; Department of Physics, Faculty of Physical Sciences, Ahmadu Bello University, Zaria

15. Nuhu G. O. (2009): The Younger Granites-Geology and Mineral Resources of Nigeria, volume 120, pp 31-48. [CrossRef]

16. Nwajei G.E., Okwagi P., Nwajei R. I and Obi-Iyeke G.E. (2012): Analytical Assessment of Trace Elements in Soils, Tomato Leaves and Fruit in the Vicinity of Paint industry, Nigeria, Res. J. Recent Sci., 1(4), 22-26.

17. Obaje S.O., Ojutalayo A., Ogedengbe O. and Okosun E.A. (2014): Nigeria's Phosphate and Uranium Mineral Occurrences - Implication for Mineral Investment, Journal of Environment and Earth Science, Vol.4. (83).

18. Ogunleye P.O. and Garba E.C.I. (2006): Factors contributing to enrichment and crystallization of niobium in pyrochlore in the Kaffo albite arfvedsonite granite, Ririwai Complex, Younger Granites province of Nigeria; Journal of African Earth Sciences, Vol. 44, Pages 372-382. [CrossRef]

19. Olure-Bank A. M. (2016): Economic Gift Source of Diversifying Nigerian Economy for Economic Growth and Economic Development Sustainability Journal of Economics and Sustainable, Development, Vol.7, 34.

20. Schwegler F. (2006): Air quality management - a mining perspective, Anglo Technical Division, South Africa, Vol. 86. [CrossRef]

21. Umar, A. (2016). Analysis of Tourism Resources in Doguwa LGA Kano Nigeria: An unpublished Master Thesis, Bayero University, Kano.

22. Zakari Y. I., Nasiru R., Ahmed Y. A. and Abdullahi, M. A. (2015): Measurement of Radon Concentration in Water Sources around Ririwai Artisanal Tin mine Kano State, Nigeria; Journal of Natural Sciences Research, Vol.5.

\section{AUTHOR PROFILE}

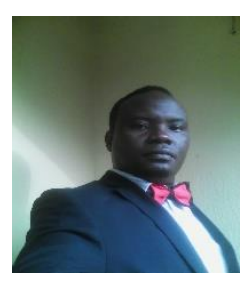

Mining Engineer, Amosu Cyril Olumuyiwa Professional background:

- $\quad$ Lecturer and researcher at Yaba College of Technology, Lagos, Nigeria. ।

- Associate Environmental Professionals (AEP), National registry Of Environmental Professionals (NREP). Nigeria (COREN).

Council for Regulation of Engineering in

\section{Education:}

- $\quad$ Master of Engineering (M. Eng.) in Mining Engineering from Federal University of Technology Akure, Nigeria (2019 - Date).

- Masters (M. Sc.) in Petroleum Engineering and Project Development (2004 - 2005).

- $\quad$ Bachelors of Engineering (B. Eng.) in Mining Engineering from Federal University of

Technology Akure, Nigeria (1995 - 2001).

Previous publishing experience

About fifteen (15) journals and conference published already with different publishers which can be found on Google Scholar, ResearchGate, Publon and Orcid. These journals captures Mining and Petroleum.

Personal details:

Married with three (3) children; lives in Lagos state, Nigeria; Personal interest is writing and research.

Contact information:

Personal E-mail: muyixx1zillion@gmail.com

Official E-mail: Cyril.amosu@yabatech.edu.ng

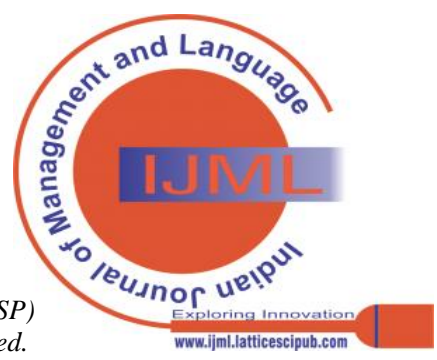

